\title{
ANÁLISE DO PROJETO DE LEI ACERCA DA PREVENÇÃO E TRATAMENTO DO SUPERENDIVIDAMENTO DO CONSUMIDOR
}

\author{
BILL ANALYSIS ON THE PREVENTION AND CONSUMER OVERINDEBTEDNESS \\ TREATMENT
}

${ }^{1}$ Leandro Moraes do Espírito Santo

\section{RESUMO}

Partindo da premissa que a população brasileira tornou-se uma população, na sua maioria, de endividados, sem que houvesse nenhum tipo de prevenção e tratamento para este fenômeno que vem sendo denominado de superendividamento, é que foi proposto o PLS 283/2012, que atualmente está tramitando no congresso nacional. Este estudo não tem a pretensão de encerrar o debate do tema, mas sim, de analisar os principais dispositivos do referido projeto que versam acerca da prevenção e do tratamento do Superendividamento do consumidor.

Palavras-chave: Superendividamento, Consumidor, Direitos fundamentais

\begin{abstract}
Assuming that the Brazilian population has a population mostly of debt, without there being any kind of prevention and treatment for this phenomenon that has been called over- indebtedness, it has been proposed PLS 283/2012, which it is currently before the national congress. This study does not intend to close the subject of debate, but rather to analyze the main provisions of the said project which focus on the prevention and consumer overindebtedness treatment.
\end{abstract}

Keywords: Overindebtedness, Consumer, Fundamental rights

\footnotetext{
${ }^{1}$ Mestrando em Direitos Fundamentais pela Universidade da Amazônia - UNAMA, Manaus Brasil. Professor de Direito Empresarial pela Universidade Federal do Pará - UFPA, Pará (Brasil).

E-mail: leandromoraes1410@gmail.com
} 


\section{INTRODUÇÃO}

A defesa do Consumidor é direito fundamental previsto no art. $5^{\circ}$. XXXII da Constituição Federal de 1988, que prescreve: “O Estado promoverá, na forma da lei, a defesa do consumidor".

Para tanto, importante compreender o que são direitos fundamentais. George Marmelstein (2014, p.17) os conceitua como sendo:

(...) normas jurídicas, intimamente ligadas à idéia de dignidade da pessoa humana e de limitação do poder, positivadas no plano constitucional de determinado Estado Democrático de Direito, que por sua importância axiológica, fundamentam e legitimam todo o ordenamento jurídico.

Nessa esteira, mister pontuar o conceito de direitos fundamentais, que, conforme Dimitri Dimoulis e Leonardo Martins (2014, p. 41) são:

(...) direitos públicos-subjetivos de pessoas (físicas ou jurídicas), contidos em dispositivos constitucionais e, portanto, que encerram caráter normativo supremo dentro do Estado, tendo como finalidade limitar o exercício do poder Estatal em face da liberdade individual.

Assim, é dever do Estado assegurar, garantir e estimular a defesa do consumidor em todos os seus âmbitos ou poderes para que em ultima análise sempre esteja atendido o principio da dignidade da pessoa humana.

Ainda, a proteção do consumidor foi considerada tão importante pelo constituinte, que no título VII da Constituição Federal de 1988, que trata da ordem econômica, elevou no art. 170, V, a defesa do consumidor ao patamar de princípio geral da atividade econômica, devendo, portanto, ser respeitado por ser o consumidor a razão de ser dos fornecedores de produtos ou de serviços.

Destarte, com o advento do Código de Defesa do Consumidor em 1990, houve resultados expressivos na tutela dos direitos dos consumidores, contudo o referido diploma não adentrou no fenômeno do superendividamento.

Em um passado recente a questão do acesso ao crédito no Brasil ainda não havia se expandido e a análise para a sua concessão se dava muito em um caráter pessoal com base na confiança entre credor e devedor. 
Contudo, com o advento da pós-modernidade ${ }^{1}$, que segundo (MARQUES, 2014) e (SARMENTO, 2008) é baseada na velocidade das transações e das informações, nos avanços da ciência e da tecnologia, na produção para o consumo em massa, nas novas formas de acesso ao crédito e de contratos em massa, inclusive virtuais, a análise do crédito para sua concessão passou a levar em conta não mais a pessoa, mas os números, os seus dados estatísticos e rendimentos.

Clarissa Costa de Lima (2014, p. 26-27) afirma:

(...) Nunca foi tão fácil pedir empréstimos e contrair dívidas. Formas particulares de crédito estão sendo constantemente desenvolvidas, neste lado do planeta assim como na América do norte e na Europa, para estimular o consumo e o crescimento econômico, constituindo um indicador importante de saúde financeira de um país.[...] Apesar das evidências de que a expansão do crédito ao consumo traz inúmeros benefícios para os consumidores e para o desenvolvimento da economia, há custos e riscos que precisam ser enfrentados, a exemplo da redução da poupança familiar, da inflação e da perpetuação do endividamento.Nos casos mais graves, as dividas superam o patrimônio do devedor (bens e rendas), impossibilitando o seu pagamento, fenômeno conhecido por superendividamento cujos efeitos extrapolam a pessoa do superendividado, pois além de ser fonte de isolamento e de marginalização, gera um custo social elevado que desafia os poderes públicos a encontrar uma solução.

Nessa senda, objetivando dar tratamento preventivo e repressivo para o fenômeno do superendividamento é que tramita o PLS 283/2012 no congresso nacional visando incluir um capítulo no Código de Defesa do Consumidor quanto ao tema.

Para chegarmos a uma resposta adequada optamos por fazer uma pesquisa que adotou a vertente jurídico-teórica, que conforme Witker (1985, apud DIAS; GUSTIN, 2002, p. 22):

(...) acentua os aspectos conceituais, ideológicos e doutrinários de determinado campo que se deseja investigar [...] deverá seguir os mesmos passos das demais, à exceção dos procedimentos metodológicos das pesquisas de campo. Isso não significa, porém, que as investigações inseridas nessa vertente não tenham natureza aplicada como as demais, visto que toda investigação no campo das ciências sociais aplicadas, deve visar uma aplicação prática, mesmo que não imediata.

Trata-se de pesquisa que adotou técnica de investigação jurídico-exploratória, que permite uma abordagem preliminar de um problema jurídico, ressaltando características percepções e descrições, podendo abrir caminhos para outras pesquisas mais profundas e com hipóteses mais precisas (WITKER, 1985 apud DIAS; GUSTIN, 2002).

\footnotetext{
1 Sobre o tema da pós-modernidade veja: MARQUES, Claudia Lima. Contratos no Código de Defesa do Consumidor: o novo regime das relações contratuais. 7 ed. rev., atual. e ampl. - São Paulo: Editora Revista dos Tribunais, 2014, p. 168 e ss. Ver também: SARMENTO, Daniel. Direitos Fundamentais e Relações Privadas. 2 ed. Rio de Janeiro: Lumen Juris, 2008, p. 36 e ss.
} 
Destarte, neste ensaio faremos um estudo crítico do que se tem chamado de fenômeno do superendividamento conceituando-o, analisando as suas principais causas e conseqüências elencadas pela doutrina.

Em seguida serão analisados criticamente os dispositivos do projeto em tela que se referem à defesa extrajudicial e em juízo, o processo de repactuação de dívidas e o processo de superendividamento, evidenciando, por fim, de que forma pretende o PLS 283/2012, contribuir para a preservação do mínimo existencial do consumidor superendividado.

\section{O SUPERENDIVIDAMENTO}

O superendividamento é um fenômeno decorrente da democratização do crédito e atinge tanto países desenvolvidos economicamente como os países ainda em desenvolvimento.

Vivemos na sociedade do consumo, da moda, do imediatismo que faz com que os indivíduos acreditem que viver bem é consumir constante e demasiadamente.

Sobre o consumismo na contemporaneidade, importante a lição de Catarina Frade e Sara Magalhães (2006, p. 25):

(...) de um ponto de vista subjetivo, a sua não realização pode acarretar prejuízos relacionados, por exemplo, com a não inclusão num círculo social com repercussões diretas no bem-estar psicológico. Assim, um indivíduo que se encontre inserido num contexto social em que a manifestação de bens materiais seja valorizada e não tiver recursos suficientes que lhe permitam a aquisição desse tipo de bens, encontra no crédito uma via para alcançar esse reconhecimento social.

Com a expansão do acesso ao crédito e a ascensão de classes na sociedade brasileira, nos últimos anos o aumento do endividamento se intensificou gerando diversos problemas para os consumidores.

Claudia Lima Marques (2014, p.1402-1403) afirma que:

$\mathrm{O}$ endividamento é um fato inerente à vida em sociedade, ainda mais comum na atual sociedade de consumo. Para consumir produtos e de serviços, essenciais ou não, os consumidores estão -quase todos- constantemente se endividando. A nossa economia de mercado seria, pois, por natureza uma economia do endividamento. Consumo e crédito são faces de uma mesma moeda, vinculados que estão no sistema econômico e jurídico de países desenvolvidos e de países emergentes, como o Brasil.

Revista de Direito, Glob. R Res nas Rel de Cons | e-ISSN: 2526-0030 | Brasília | v. 2 | n. 1 | p. 113-129 |Jan/Jun. 2016. 
Esse fenômeno pode ser conceituado a partir de diferentes critérios, mas Clarissa Costa de Lima (2014, p.34) identificou que em todos os aspectos existe um traço comum: "a impossibilidade do devedor de pagar todas as suas dividas, atuais e futuras, com seu patrimônio e seu rendimento".

Para Claudia Lima Marques (2006, p.256):

o superendividamento pode ser definido como a impossibilidade global de o devedor-pessoa física, consumidor, leigo e de boa fé, pagar todas as suas dívidas atuais e futuras de consumo (excluídas as dividas com o fisco, oriundas de delitos e de alimentos).

Observa-se no substitutivo aprovado pela Comissão de Constituição e Justiça em 05/08/2015, no parágrafo primeiro do art. 54-A do PLS 283/2012, o superendividamento foi definido da seguinte forma:

(...) Entende-se por superendividamento a impossibilidade manifesta do consumidor, pessoa natural, de boa-fé, de pagar o conjunto de suas dívidas de consumo, exigíveis e vincendas, que comprometa seu mínimo existencial, nos termos da regulamentação.

A disciplina jurídica e legal do superendividamento já se encontra avançada em diversos países. ${ }^{2} \mathrm{O}$ fato destes países já contarem com legislação específica para prevenção e combate ao fenômeno supramencionado, por si só, já prova que este é um fenômeno social e jurídico global que não é exclusivo de países em desenvolvimento, mas de qualquer sociedade de consumo ativa. Inspirado no sistema acima foi proposto o PLS 283/2012 que atualmente tramita no Congresso Nacional.

Em linhas gerais, o referido projeto visa criar um sistema de prevenção e tratamento extrajudicial e judicial do superendividamento do consumidor pessoa natural, promover o acesso ao crédito responsável e à educação financeira do consumidor, de forma a evitar sua exclusão social e o comprometimento de seu mínimo existencial, com base nos princípios da boa-fé, da função social do crédito ao consumidor e do respeito à dignidade da pessoa humana. ${ }^{3}$

\footnotetext{
${ }^{2}$ Sobre o sistema na França veja: LIMA, Clarissa Costa de. O tratamento do superendividamento e o direito de recomeçar dos consumidores. -São Paulo: Editora Revista dos Tribunais, 2014, pág. 83 e ss. Sobre os demais países ver: Lima, Clarissa Costa de; Bertoncello, Karen Rick Danielvicz. Tratamento do crédito ao consumo na América Latina e superendividamento. In: MARQUES, Claudia Lima; CAVALLAZZI, Rosângela Lunardelli (coord.) Direitos do consumidor endividado. São Paulo: Ed. RT, 2006, p. 191-210.

${ }^{3}$ PLS 283/2012 disponível em:<http://www.senado.gov.br/atividade/materia/detalhes.asp?p_cod_mate=106773> acesso em 06/06/2015.
} 
O referido tema já foi objeto de audiência pública no Senado, onde diversos juristas de renome participaram do debate. Dentre os pontos abordados, restou clara a preocupação com a prevenção do superendividamento, como forma de proteger o consumidor do risco e dos perigos do crédito fácil e irresponsável, de dividir a responsabilidade pelo endividamento também com os fornecedores, concretizada pelo princípio do crédito responsável e a prevenção contra crises econômicas, como: a recente crise experimentada pelos Estados Unidos da América.

Igualmente foram abordadas questões como, a necessidade de atualizar o Código de Defesa do Consumidor para evitar a exclusão social do consumidor endividado, estabelecer a obrigatoriedade do dever de cooperação e lealdade entre fornecedor e consumidor, como: informar e alertar o consumidor, e, quando necessário, renegociar as dívidas para evitar que o consumidor seja levado à ruína. ${ }^{4}$

Outra discussão são os fatores elencados na doutrina como causadores do superendividamento. Segundo Niemi-Kiesilainen (2003, apud LIMA, 2014, p.35) "o superendividamento só existe quando o crédito é utilizado pelos consumidores; logo, o crédito é a principal razão para o superendividamento”. Destarte, independentemente de qual a causa que desencadeou o superendividamento, a principal delas é o crédito.

Entre as principais causas do superendividamento estão os problemas dos direitos econômicos e sociais como: desemprego e a baixa qualidade de serviços públicos como a educação e a saúde, além de deficiências em finanças pessoais e acesso a informação de qualidade e completas acerca das condições de eventual contratação levando-se em conta os custos totais efetivos de uma operação.

Segundo o Senador Ricardo Ferraço (2014, p. 27):

As piores armadilhas para o consumidor são as ofertas de dinheiro fácil e as promoções tentadoras de bens e de produtos, com prestações que cabem em qualquer bolso. Propagandas muitas vezes enganosas, cláusulas contratuais mal explicadas e abordagens até mesmo agressivas para tomada de crédito popular acabam confundindo os mais desavisados e levando ao superendividamento.

Os motivos acima expostos corroboram com o conceito formulado na Europa de superendividamento passivo e ativo. Assim, no superendividamento passivo o consumidor

\footnotetext{
${ }^{4}$ Sobre o debate em audiência pública no senado ver: TV Senado. Clarissa Costa de Lima (Brasilcon) alerta para a importância de se prevenir o superendividamento. Disponível em: < https://www.youtube.com/watch?v=_satwNewuI> Acesso em 06/06/2015. Ver também: TV Senado. Cláudia Lima Marques (Com. Juristas) critica a falta de renegociação com as pessoas endividadas. Disponível em: < https://www.youtube.com/watch?v=WSZ68yIuFjo> Acesso em 06/06/2015.
} 
não contribuiu de forma ativa para o seu endividamento (desemprego, divórcio, doenças etc.), já no superendividamento ativo, este se divide em consumidor consciente e inconsciente, sendo o primeiro aquele que de má-fé contraiu dividas restando, portanto, excluído do abrigo legal do tratamento, e os inconscientes aqueles que de boa-fé contraíram dividas acreditando que honrariam com suas obrigações. (LIMA, 2014)

No Brasil, pesquisas recentes apontam que mais de $60 \%$ da população está endividada ${ }^{5}$. Dentre os resultados das pesquisas verificou-se que a maior parte da dívida em atraso é proveniente de cheque especial, cartão de crédito, parcelas do carro, carnê de lojas e de despesas de serviços como água, luz e planos de saúde.

Entre as causas acima expostas Clarissa Costa de Lima (2014, p. 39), evidencia:

A predominância dos casos de superendividamento passivo verificou-se, igualmente, nos 2.486 casos atendidos até 2011 no Poder Judiciário do rio Grande do Sul pelo projeto de Tratamento das Situações de Superendividamento do Consumidor, apurando-se $22,8 \%$ de superendividamento causado pelo desemprego; $4,7 \%$ por motivo de separação/divórcio ou dissolução de união estável; $19 \%$ em razão de doença pessoal ou familiar; $2,5 \%$ em razão da morte de alguém que contribuía para o orçamento doméstico e $24,3 \%$ por outros motivos relacionados à redução de renda.

Os impactos e conseqüências causados pelo superendividamento são complexos e desencadeiam outros problemas na vida do individuo e de terceiros, bem como no desenvolvimento econômico e social, o que acaba por ferir a própria Constituição Federal de 1988, visto que impossibilita o cumprimento dos objetivos fundamentais delineados no seu art. $3^{\circ}$, bem como viola o principio da dignidade da pessoa humana impossibilitando ao individuo de ter preservado o mínimo existencial para a sua vida e de sua família.

Para Henrique Mariano (2014, p. 28):

O superendividamento representa vicissitude social de grande magnitude, geradora de circunspectas patologias psíquicas e fonte de desestabilização do núcleo familiar. A expansão incomensurável do acesso ao crédito e a facilitação de aquisição de produtos e serviços suscitou o comprometimento da renda familiar e pessoal, inviabilizando o sustento de aspectos básicos da condição de vida de milhares de consumidores de boa-fé.

Dentre os efeitos provenientes do superendividamento destacamos: impossibilidade manifesta do individuo de prover para si próprio e para sua família bens e serviços considerados como vitais como: água, luz, alimentação, educação, saúde e moradia;

5 Pesquisa realizada pela confederação nacional do comércio de bens, serviços e turismo divulgada em 27/05/2015, disponível em: http://www.cnc.org.br/sites/default/files/arquivos/release_peic_maio_2015.pdf acesso em: 06/06/2015. 
problemas familiares entre cônjuges e entre pais e filhos; surgimento de problemas psicológicos ou psíquicos; cenário propício para crise econômico-financeira e social; aumento da marginalização e informalidade da economia; aumento das desigualdades, violência e pobreza.

Davis e Mantler (2004, apud LIMA, 2014, p. 40) apontam resultados de pesquisa no centro de pesquisa em estresse e bem-estar da Universidade de Carleton, no Canadá concluindo que:

O estresse causado pelo endividamento excessivo está associado à baixa autoestima, visão pessimista da vida, redução da saúde com aumento de casos de dores de cabeça e de estômago, insônia, depressão, podendo levar ao consumo exacerbado de álcool e até mesmo ao suicídio.

Em casos mais delicados o consumidor superendividado acaba por ficar sem renda, quando, por exemplo, concentra seu salário em conta na qual também vem utilizando o cheque especial e recebe o desconto referente à fatura do cartão de crédito.

Nestes casos, o consumidor fica impossibilitado de cumprir com suas obrigações básicas e essenciais como pagamento das contas de energia, água, alimentação, educação e plano de saúde.

Quando isto ocorre é que o consumidor se dá conta da sua situação, percebe que já está num ciclo vicioso sem fim, que desencadeia outros problemas familiares, podendo gerar eventos de violência doméstica, psicológicos e profissionais, inclusive desaguar no seu desemprego, o que agravaria ainda mais a sua situação.

Neste sentido o Senador Ricardo Ferraço (2014, p.27) sentencia:

Não podemos esquecer que a médio e longo prazos, o superendividado é excluído do mercado de consumo. Mais: o superendividamento também contribui para o aumento da violência doméstica e da criminalidade e, fora de controle, ameaça o desenvolvimento sustentável da economia.

Para proteção do mínimo existencial do consumidor superendividado, fundamental a criação de normas eficazes que possibilitem a solução para a questão do endividamento do consumidor de forma global. É o que passamos a analisar com base no PLS 283/2012. 


\section{ANÁLISE DOS PRINCIPAIS ARTIGOS DO PLS 283/2012}

Primeiro ponto a ser discutido é o conceito de superendividamento, citado anteriormente, estampado no parágrafo primeiro do art. 54-A. Parece-nos que estamos tratando do mesmo conceito de insolvência, nos termos do art. 748 do Código de Processo Civil de 1973 que dispõe: "Dá-se a insolvência toda vez que as dívidas excederem à importância dos bens do devedor." A única diferença que encontramos é que superendividamento, conforme o conceito do art. 54-A, trata-se apenas de dívidas de consumo.

Segundo ponto a ser criticado é o fato de que o projeto somente se aplica ao devedor pessoa natural, inicialmente o projeto utilizava a expressão "pessoa física". Na verdade, pensamos que o que queria ser dito é devedor pessoa física ou natural não empresário, pois a pessoa natural também pode ser empresária. A idéia era distinguir o consumidor empresário do não empresário, já que o empresário possui a recuperação judicial (lei 11.101/2005). Todavia, o referido projeto exclui os demais devedores não empresários, como associações, sociedades não empresárias e etc.

Outra crítica diz respeito à natureza das dívidas. Devem ser somente dívidas de consumo. Assim, teremos mais um diploma normativo que envolva execução concursal ou tratamento de insolvência em separado dos outros existentes como a lei 11.101/2005 (Lei de Recuperação e falências e empresas) e Insolvência Civil (CPC/73).

Após a conceituação de superendividamento formulada no parágrafo primeiro do artigo 54-A outrora apresentada, faz-se necessário ressaltar que o legislador preocupou-se em deixar claro que a lei não se aplica às dívidas contraídas mediante fraude ou má-fé oriundas de contratos celebrados dolosamente com o propósito de não realizar o pagamento (artigo 54A, parágrafo terceiro).

Entre as diversas práticas que visam a prevenção do superendividamento, destacamos o disposto no artigo 54-C, caput e parágrafos, no que tange a oferta de crédito ao consumidor sendo ela publicitária ou não. Dentre as principais proibições estão: fazer referência a crédito "sem juros", "gratuito", "sem acréscimo", com "taxa zero" ou expressão de sentido semelhante (artigo 54-C, I) e indicar que a operação de crédito poderá ser concluída sem consulta a serviços de proteção ao crédito ou sem avaliação da situação financeira do consumidor (artigo 54-C, II).

Item importante do projeto em comento é o artigo 54-D e incisos, que dispõe que o fornecedor ou intermediário na oferta do crédito, deve previamente à contratação, tomar uma 
série de medidas, tais como: levar em consideração a condição do consumidor no momento de informar e ofertar sobre o produto e os seus riscos, observando a idade, saúde, conhecimento e condição social. Deve também realizar análise de crédito de forma criteriosa, solicitando ao consumidor documentação comprobatória das informações cadastrais preenchidas.

O parágrafo único do artigo 54-D dispõe que, o descumprimento de qualquer dos itens do artigo 52 e 54-C, poderá acarretar judicialmente a inexigibilidade ou a redução dos juros, encargos, ou qualquer acréscimo ao principal, bem como a dilação do prazo para pagamento originalmente contratados, conforme a gravidade da conduta do fornecedor e as possibilidades financeiras do consumidor, sem prejuízo de indenizações e sanções.

O referido projeto deu atenção especial para os empréstimos consignados fixando o percentual máximo de 30\% (trinta por cento) da remuneração mensal líquida do consumidor, ensejando o seu descumprimento no imediato dever de revisão ou renegociação, concedendo ao juiz o poder de adotar diversas medidas como: dilação de prazo para pagamento, redução de encargos da dívida, substituição de garantias e etc. ( artigo 54-E parágrafos).

\subsection{Da repactuação de dívidas}

Vejamos o que dispõe o caput do art. 104-A do referido projeto de lei no tocante à conciliação:

A requerimento do consumidor superendividado pessoa natural, o juiz poderá instaurar processo de repactuação de dívidas, visando à realização de audiência conciliatória, presidida por ele ou por conciliador credenciado no juízo, com a presença de todos os credores, em que o consumidor apresentará proposta de plano de pagamento com prazo máximo de cinco anos, preservado o mínimo existencial e as garantias originalmente pactuadas.

No PLS 283/2012 resta claro o objetivo de preservar o mínimo existencial do consumidor, por exemplo, por meio da revisão e repactuação de dívidas, conforme art. $6^{\circ}$, XI e art. $104-\mathrm{A}$, do referido projeto.

Nas palavras de Barroso (2011, p. 202 apud MASSON, 2015, p. 294), o mínimo existencial pode ser definido como um:

(...) conjunto de condições materiais essenciais e elementares cuja presença é pressuposto da dignidade para qualquer pessoa. Se alguém viver abaixo daquele patamar, o mandamento constitucional estará sendo ferido. 
Destarte, uma pessoa superendividada pode vir a ter afetado o seu mínimo existencial. Em outras palavras, um indivíduo superendividado fica impossibilitado de desenvolver-se em sociedade, uma vez que, as suas liberdades foram suprimidas ou reduzidas de tal forma, que não existe espaço para decisões ou escolhas de modo de vida. Conseqüientemente, este indivíduo não estará em condições iguais aos outros indivíduos para se buscar o bem-estar.

O Senador Rodrigo Ferraço (2014, p. 27), afirma que o objetivo do PLS 283/2012 é "preservar o mínimo existencial, compreendido como a quantia mínima destinada à manutenção das despesas mensais razoáveis de sobrevivência, como água, luz, alimentação, saúde, moradia e educação".

Este conceito de mínimo existencial foi retirado do texto do referido projeto sendo substituído pela expressão "nos termos da regulamentação", haja vista, a dificuldade em se chegar num consenso acerca do que viria a ser o mínimo existencial num plano objetivo.

No último dia 05/08/2015, a CCJ emitiu o substitutivo atualizado com a expressão acima em diversos artigos, Vejamos, por exemplo, o que dispõe o artigo $6^{\circ}$, XI e XII:

Art. $6(\ldots)$

XI- a garantia de práticas de crédito responsável, de educação financeira, de prevenção e tratamento das situações de superendividamento, preservando o mínimo existencial, nos termos da regulamentação, por meio da revisão e repactuação da dívida, entre outras medidas;

XII- na repactuação de dividas e na concessão de crédito, a preservação do mínimo existencial, nos termos da regulamentação;

Nessa esteira, é perfeitamente sustentável a necessidade de prevenção e tratamento do superendividamento como forma de manter o mínimo existencial e em ultima análise atender ao principio da Dignidade da Pessoa Humana.

Na fase conciliatória, denominada de processo de repactuação de dívidas, o juiz, a pedido do consumidor, poderá instaurar tal processo para realização de audiência conciliatória que deverá ser presidida por ele ou conciliador credenciado no juízo, com a presença de todos os credores, em que o consumidor apresentará proposta de plano de pagamento com prazo máximo de cinco anos, preservado o mínimo existencial, as garantias e formas de pagamento originalmente pactuadas (art. 104-A).

Entretanto, não são todas as dívidas que poderão ser incluídas no processo de repactuação de dívidas, estando excluídas aquelas de caráter alimentar, fiscais e parafiscais e as oriundas de contratos celebrados dolosamente sem o propósito de realizar o pagamento, bem como, os contratos de financiamento imobiliário, com garantia real e os contratos de crédito rural. (art. 104-A, parágrafo primeiro). 
Merece crítica a não inclusão de contratos de financiamento imobiliário, com garantia real e os contratos de crédito rural, decisão proveniente de emenda, sendo justificada pela comissão como necessária para preservar as linhas de crédito com taxas incentivadas e que contam com subsídio público. Ainda, segundo a comissão, estas operações devem ser preservadas em sua integralidade, para propiciar a efetividade das políticas públicas de crédito.

Discordamos deste entendimento, haja vista que, em muitos casos a evolução do endividamento encontra-se avançada de tal maneira, que somente uma medida de repactuação de dívida teria eficácia para evitar que o consumidor tenha seu imóvel, ou bem móvel retomado pela instituição financeira credora como forma de recuperar o crédito concedido.

Mais: Numa eventual repactuação de dívidas ou processo de superendividamento, como aceitar que o consumidor mantenha o seu mínimo existencial, se, eventualmente, ao compor todas as suas dívidas acabar tendo que ser retirado de seu imóvel por inadimplência? Neste caso entendemos que a eficácia do referido projeto ficaria comprometida.

Seguindo com a análise, caso o credor não compareça injustificadamente à audiência de conciliação, o juiz determinará medida que acarretará na suspensão da exigibilidade do débito e na interrupção dos encargos da mora (art. 104-A, parágrafo segundo).

No plano deverão constar as medidas utilizadas para repactuação da dívida como dilações de prazo, redução de encargos e etc. Deverá também fazer referência a eventuais suspensões ou extinções de ações judiciais em curso; indicar a data a partir da qual será providenciada a exclusão do consumidor de banco de dados e cadastros de inadimplentes e condições a serem seguidas pelo consumidor no sentido de abster-se de praticar condutas que importem no agravamento de sua situação financeira (art. 104-A, parágrafo quarto).

Em caso de conciliação, que poderá ser parcial, a sentença que homologar o acordo descreverá o plano de pagamento da dívida, terá força de titulo executivo e força de coisa julgada (art. 104-A, parágrafo terceiro).

Ainda na fase conciliatória, importante mencionar que os órgãos que compõem o Sistema Nacional de Defesa do Consumidor poderão concorrentemente atuar na fase de conciliação e preventiva do processo de repactuação de dívidas. (art. 104-C).

Por fim, o pedido feito pelo consumidor não importa em declaração de insolvência civil e poderá ser repetido somente depois de decorrido o prazo de dois anos, contados da liquidação das obrigações previstas no plano de pagamento homologado (art. 104 -A, parágrafo quinto) 


\subsection{Do processo de superendividamento}

A nosso ver, questão processual mais importante abordada no PLS 283/2012 é o processo de superendividamento. Destarte, sendo inexitosa a conciliação, a pedido do consumidor, o juiz instaurará o processo de superendividamento para revisão e integração dos contratos e repactuação de dívidas remanescentes através de um plano judicial compulsório, procedendo à citação de todos os credores cujos créditos não integraram o acordo celebrado (art. 104-B, caput).

Os credores terão 15 (quinze) dias para juntar documentos e as razões para a negativa de aderir ao plano voluntário ou de renegociar (art. 104-B, parágrafo primeiro).

O juiz poderá ainda nomear um administrador para apresentar o plano de pagamento no prazo de até 30 (trinta) dias depois de cumpridas as diligências necessárias, desde que, não onere as partes, podendo apresentar medidas de temporização ou de atenuação de encargos (art. 104-B, parágrafo segundo).

Merece nota o dispositivo acima mencionado. O projeto de lei não esclarece os critérios para nomeação do administrador pelo juiz nem tampouco como esse administrador será remunerado já que tal nomeação não poderá onerar as partes. Quem poderá ser administrador judicial? Quem aceitará ser administrador judicial sem perceber qualquer remuneração?

O projeto de lei em comento, no plano judicial compulsório, assegura aos credores, no mínimo, o valor do principal devido corrigido monetariamente por índices oficiais de preço, e preverá a liquidação total da dívida em no máximo, cinco anos, sendo a primeira parcela devida no prazo máximo de cento e oitenta dias, contados da sua homologação judicial, e o restante do saldo devido mensalmente em parcelas iguais e sucessivas (art. 104-B, parágrafo terceiro).

Preocupa-nos o poder que o juiz terá em suas mãos para decidir acerca do plano compulsório no caso de restar infrutífera a composição entre as partes. Desta forma, ainda que os credores não aprovem o plano de pagamento ou de repactuação apresentado, o juiz poderá aprovar o plano compulsório, o que pode não ser bem recepcionado pelos fornecedores de produtos ou de serviços que sentirem-se prejudicados. Entendemos que esta situação gera insegurança jurídica para os credores e desestimula a redução do custo do crédito.

Talvez o legislador devesse buscar inspiração na lei de recuperação e falência de empresas (lei 11.101/2005), particularmente na recuperação de micro e pequenos empresários, onde o plano pode ser aprovado pelo juiz sem necessidade de convocação de assembléia, mas 
permitindo a sua não aprovação no caso de objeções de mais da metade dos credores, conforme art. 70 e seguintes da referida lei.

Questões como a autonomia da vontade dos credores de optarem em aprovar ou não aprovar o plano, como também identificar em quais casos os consumidores não poderá valerse do processo de repactuação de dívidas e do processo de superendividamento pelo fato de terem agido de má-fé, além de questões recursais não ficaram bem delineadas e merecem maior atenção antes de eventual sanção da lei.

\section{CONCLUSÃo}

A Constituição Federal de 1988 estabeleceu no art. 1º III, o Principio da Dignidade da Pessoa Humana, como um de seus fundamentos e elencou entre os principais objetivos no art. $3^{\circ}$, I e III, construir uma sociedade livre, justa e solidária e erradicar a pobreza.

Os direitos do consumidor foram elevados ao patamar de direitos fundamentais art. $5^{\circ}$, XXXII e de princípios gerais da atividade econômica. Art. 170, V, da Constituição Federal de 1988.

Contudo, evidenciamos que o fenômeno do superendividamento vem crescendo nos últimos anos da sociedade brasileira e trazendo consigo diversas conseqüências que ofendem os mandamentos constitucionais acima expostos, sem, contudo, até o momento, contar com nenhuma disciplina legal específica para prevenção e tratamento deste fenômeno.

Ressaltamos que está em tramitação no congresso nacional o PLS 283/2012 que visa alterar o Código de Defesa do Consumidor para criar um capítulo objetivando a prevenção e tratamento do superendividamento, tendo sido recentemente aprovado pela Comissão de Constituição e Justiça, com alterações.

Analisamos os principais dispositivos do referido projeto que tratam da prevenção e tratamento do consumidor superendividado, apontando os benefícios que podem trazer para o consumidor, mas também constatamos a existência de dispositivos que precisam de maior atenção, para melhor atingir o objetivo do projeto.

Registramos nossa critica. Superendividamento parece ter o mesmo significado jurídico que insolvência, ou ao menos se assemelha bastante. Tratando-se de não empresários, temos a insolvência civil, processo disposto no CPC/73.

Não é novidade que a insolvência civil apresenta problemas no tocante à recuperação do devedor não empresário, motivo pelo qual entendemos que o referido projeto perde uma imensurável oportunidade de dar nova roupagem ao instituto da insolvência civil, próprio dos 
devedores não empresários. Neste sentido importante mencionar que o Código de Processo Civil de 2015 no seu art. $1052{ }^{6}$ deixou para lei específica tratar da insolvência civil, continuando a até sua edição a ser regida pelos dispositivos do CPC/73.

Ao contrário, cria novo mecanismo judicial de tratamento de insolvência somente para devedores consumidores ao incluir referido processo no Código de Defesa do Consumidor, dificultando ainda mais uma unificação e fortalecimento de estatutos reguladores de insolvência e excluindo dos processos de repactuação e de superendividamento os devedores não empresários que não sejam consumidores e pessoa natural.

Ademais, no processo de superendividamento entendemos que existe perigo real de insegurança jurídica por dar poderes demais ao juiz, sem firmar regras bem delineadas acerca do pagamento do administrador, do seu perfil profissional, para decidir sobre o plano compulsório e também sobre as possibilidades de recursos para aqueles que sentirem-se prejudicados.

Por fim, evidenciamos a necessidade de se estabelecer o quanto antes uma disciplina legal que viabilize a prevenção e tratamento do superendividamento ou da crise de insolvência para garantir os direitos fundamentais dos consumidores, o seu mínimo existencial e atender ao Principio da Dignidade da Pessoa Humana e da Igualdade.

\section{REFERÊNCIAS}

BERTONCELLO, Karen Rick Danielvicz; LIMA, Clarissa Costa de. Tratamento do crédito ao consumo na América Latina e superendividamento. In: MARQUES, Claudia Lima; CAVALLAZZI, Rosângela Lunardelli (coord.) Direitos do consumidor endividado. São Paulo: Ed. RT, 2006, p. 191-210.

BRASIL. Congresso Nacional. Projeto de Lei $n^{o}$. 283/2012. Disponível em: <http://www.senado.gov.br/atividade/materia/detalhes.asp?p_cod_mate=106773>. Acesso em 06/06/2015.

. Constituição da República Federativa do Brasil, de 05 de outubro de 1988. Diário Oficial da União. Brasília, 1988. Disponível em: < http://www.planalto.gov.br/ccivil_03/constituicao/constituicaocompilado.htm> Acesso em: 06/06/2015.

. Código de Defesa do Consumidor, de 11 de setembro de 1990. Diário Oficial da União. Brasília, 1990. Disponível em:< http://www.planalto.gov.br/ccivil_03/leis/18078.htm> Acesso em: 06/06/2015.

\footnotetext{
6 “Art. 1.052. Até a edição de lei específica, as execuções contra devedor insolvente, em curso ou que venham a
} ser propostas, permanecem reguladas pelo Livro II, Título IV, da Lei n ${ }^{\circ} 5.869$, de 11 de janeiro de 1973 ”. 
. Código de Processo Civil, de 11 de janeiro de 1973. Disponível em: < http://www.planalto.gov.br/ccivil_03/leis/L5869.htm> Acesso em 10/12/2015.

. Código de Processo Civil, de 16 de março de 2015. Disponível em: < http://www.planalto.gov.br/ccivil_03/leis/L5869.htm> Acesso em 10/01/2016.

. Lei de Recuperação judicial, extrajudicial e falência do empresário e da sociedade empresária, de 9 de fevereiro de 2005. Disponível em: < http://www.planalto.gov.br/ccivil_03/_ato2004-2006/2005/lei/111101.htm> Acesso em 10/01/2016.

CNC. Pesquisa endividamento e inadimplência do consumidor. Disponível em: < http://www.cnc.org.br/sites/default/files/arquivos/release_peic_maio_2015.pdf >. Acesso em 06/06/2015.

DIAS, Maria Tereza Fonseca; GUSTIN, Miracy Barbosa de Souza. (Re) Pensando a pesquisa jurídica: teoria e prática. Belo Horizonte: Del Rey, 2002.

DIMOULIS, Dimitri; MARTINS, Leonardo. Teoria geral dos direitos fundamentais. $5^{\mathrm{a}}$ ed. rev., atual. e ampl.- São Paulo: Atlas, 2014.

FERRAÇO, Ricardo. Superendividamento do paraíso ao inferno. Revista Jurídica Consulex.Brasília, ano XVIII- $\mathrm{n}^{\circ} .417,1^{\circ}$ de junho de 2014, p. 26-27.

FRADE, Catarina; MAGALHÃES, Sara. Sobreendividamento, a outra face do crédito. In: MARQUES, Claudia Lima; CAVALLAZZI, Rosângela Lunardelli (coord.) Direitos do consumidor endividado. São Paulo: Ed. RT, 2006.

MARIANO, Henrique. Aspectos do superendividamento. Revista Jurídica Consulex.Brasília, ano XVIII- $n^{\circ} .417,1^{\circ}$ de junho de 2014 , p.28-29.

MARMELSTEIN, George. Curso de direitos fundamentais. - 5 ed. São Paulo: Atlas, 2014.

MARQUES, Claudia Lima. Sugestões para uma lei sobre o tratamento do superendividamento de pessoas físicas em contratos de crédito ao consumo: proposições com base em pesquisa empírica de 100 casos no Rio Grande do Sul. In: MARQUES, Claudia Lima; CAVALLAZZI, Rosângela Lunardelli (coord.) Direitos do consumidor endividado. São Paulo: Ed. RT, 2006.

Contratos no Código de Defesa do Consumidor: o novo regime das relações contratuais. 7 ed. rev., atual. e ampl. - São Paulo: Editora Revista dos Tribunais, 2014.

MASSON, Nathalia. Manual de direito constitucional. 3 ed. rev. ampl. e atual. Bahia: Editora JusPodivm, 2015.

LIMA, Clarissa Costa de. O tratamento do superendividamento e o direito de recomeçar dos consumidores. -São Paulo: Editora Revista dos Tribunais, 2014. 
SARMENTO, Daniel. Direitos Fundamentais e Relações Privadas. 2 ed. Rio de Janeiro: Lumen Juris, 2008.

TV Senado. Clarissa Costa de Lima (Brasilcon) alerta para a importância de se prevenir o superendividamento. Disponível em: < https://www.youtube.com/watch?v=_sat-wNewuI > Acesso em 06/06/2015.

TV Senado. Cláudia Lima Marques (Com. Juristas) critica a falta de renegociação com as pessoas endividadas. Disponível em: < https://www.youtube.com/watch?v=WSZ68yIuFjo > Acesso em 06/06/2015. 